\title{
Forward Osmosis for Produced Water Treatment: A Comprehensive Review
}

\author{
1Shafiq Mohd Hizam, ${ }^{2 *}$ Muhammad Roil Bilad, ${ }^{1}$ Nik Abdul Hadi Md Nordin, \\ ${ }^{2}$ Norazanita Shamsuddin \\ ${ }^{1}$ Chemical Engineering Department, Universiti Teknologi PETRONAS, 32610 Bandar Seri Iskandar, \\ Perak, Malaysia \\ ${ }^{2}$ Faculty of Integrated Technologies, Integrated Sciences Building, Universiti Brunei Darussalam, \\ Jalan Universiti, BE1410, Brunei Darussalam \\ *Corresponding Author e-mail: roil.bilad@ubd.edu.bn
}

Received: September 2021; Revised: October 2021; Published: November 2021

\begin{abstract}
During crude oil and natural gas extraction from a reservoir, a large amount of water is also produced. The water fraction contains oil, grease, organic and inorganic constituents, called produced water (PW). Over the years, efficient treatment of PW has been concerned. PW has been treated with various technologies, namely floatation, filtration, coagulation/flocculation, or biological processes. Those technologies were assembled to achieve discharge standards while minimizing the cost. Exploration of membrane-based technologies for the treatment of PW has recently been reported, including the emerging forward osmosis (FO) process. This paper reviews the research progress on the FO process for PW treatment. A brief introduction to the traditional treatment technologies is first provided. Next, the basics of the FO process and research progress on the application of FO on PW treatment are discussed. Finally, techniques for fouling control in FO are reviewed, namely osmotic backwashing, ultrasound, chemical cleaning, and air sparging.
\end{abstract}

Keywords: forward osmosis; produced water; fouling control

How to Cite: Mohd Hizam, S., Bilad, M. R., Md Nordin, N. A. H., \& Shamsuddin, N. (2021). Forward Osmosis for Produced Water Treatment: A Comprehensive Review. Jurnal Penelitian Dan Pengkajian Ilmu Pendidikan: E-Saintika, 5(3), 253-272. https://doi.org/10.36312/esaintika.v5i3.542

https:// doi.org/10.36312/esaintika.v5i3.542

Copyright@ 2021, Mohd Hizam et al This is an open-access article under the CC-BY-SA License.

\section{INTRODUCTION}

The improvements in the quality of human life are often accompanied by the increasing demand for energy and clean water. With recent advancements in horizontal drilling, it is predicted by 2035 that around $45 \%$ of natural gas will be extracted in the U.S alone (B. G. Rahm \& Riha, 2012; D. Rahm, 2011). Often, rapid increases in production and exploration are matched by the demand for freshwater and wastewater production. Furthermore, the most significant wastewater associated with oil and gas production is produced water (PW) (Veil, Puder, Elcock, et al., 2004). One report stated that around $3800 \mathrm{~m}^{3}$ of freshwater is consumed per oilfield during the drilling phase (Coday et al., 2014). These water slurries are injected in hydraulic fracturing to recover oil from the oilfield formation for enhanced oil recovery. The recovered stream composed mainly of water, oil, grease, and other salt content is PW. Efficient treatment of PW thus becomes a pressing issue to be addressed. 
Generally, PW consists of organic and inorganic matters, dispersed oil, grease, hydrocarbon, and salts (Johnson et al., 2008; Veil, Puder, \& Elcock, 2004), although the content of one well varies from another. The salt content can be expressed in salinity (measured in conductivity) or as total dissolved solids (TDS). At the same time, organic and inorganic constituents may be expressed in hardness or scaling (where $\mathrm{Ca}, \mathrm{Mg}, \mathrm{Ba}$, and $\mathrm{S}$, as an example, are the agent for hardness and scaling). Since these constituents in PW are of high concentration, they can threaten the ecosystem and devastate the environment if not managed properly.

Whilst conventional treatments can treat PW, these methods are often associated with high treatment costs. Moreover, these require chemical usage (i.e., for media regeneration), media replacement, generation of secondary waste, larger footprint, and in some cases, a series of post-treatment as a polishing step. Therefore, most researchers have turned their attention towards membrane separation technologies. Membrane technologies employ a semi-permeable membrane that separates contaminants (based on their relative size towards membrane pore size) while allowing water to permeate. Some established processes, mainly the pressuredriven membrane, can achieve acceptable discharge quality, though various improvements of the processes are still possible (Çakmakce et al., 2008; Ebrahimi et al., 2009; Fakhru'l-Razi et al., 2009; Hickenbottom et al., 2013; Hutchings et al., 2010). Typical membrane processes for PW treatment are pressure-driven. They are microfiltration (MF), ultrafiltration (UF), nanofiltration (NF), and reverse osmosis (RO). The pressure-driven membrane process can treat the PW due to its ability to discriminate oil molecules (He \& Jiang, 2008). Although widely used, they are still prone to membrane fouling (E.-S. Kim et al., 2011; Sutzkover-Gutman \& Hasson, 2010). Severe fouling is mainly promoted by high pressure, which renders the fouling to be more irreversible (Lee et al., 2010). Pressure-driven membrane processes are often accompanied by cost-inefficient series of pre-treatments to accommodate the high fouling propensity (Coday et al., 2014a). Moreover, depending on the region, the PW may have a high salinity level. Applying pressure-driven membrane (i.e., RO) is not cost-effective (Al-Furaiji, 2016) or impractical due to the high magnitude of required pressure.

To minimize the tendency of membrane fouling, utilizing other types of membrane processes is open for exploration. Forward osmosis (FO) in this context is preferable and worth investigating. Contradicts with the RO concept in which transport is driven by pressure, $\mathrm{FO}$ uses osmotic pressure difference as the driving force for mass transport. The process requires a high salinity draw solution (DS) and a low salinity of wastewater (feed) in contact with the FO membrane to facilitate mass transport of pure water from the feed to the draw side and reverse salt to a much lesser degree transport in the opposite direction. Since the osmotic process occurs naturally, it does not require high pumping energy as in $\mathrm{RO}$, except for recirculation of feed and DS. FO also offers numerous advantages, such as high salt rejection, high TDS removal, and a low membrane fouling propensity. Hence, this paper reviews the conventional treatment method for PW and FO as an emerging alternative. First, a brief introduction to the traditional treatment technologies for PW treatment is provided. Next, the short fundamental of the FO process and research progress on its applications for PW treatment are discussed. Finally, techniques for fouling control, namely osmotic backwashing, ultrasound, chemical cleaning, and air sparging in FO, were also reviewed. 


\section{CONVENTIONAL TREATMENT FOR PRODUCED WATER}

Several technologies have been applied to treat PW. Table 1 outlines the summary of conventional PW treatments. Some conventional methods are adsorption, ion exchange, media filter, gas flotation, evaporation pond, freeze-thaw evaporation, and electrodialysis.

Table 1. Summary of Conventional PW Treatment

\begin{tabular}{|c|c|c|c|}
\hline Method & Description & Advantage & Disadvantage \\
\hline Adsorption & $\begin{array}{l}\text { Adsorbs contaminants } \\
\text { from the influent } \\
\text { stream via porous } \\
\text { media }\end{array}$ & $\begin{array}{l}\text { Uses compact packed } \\
\text { bed modules, able to } \\
\text { remove BTEX, TOC, } \\
\text { and heavy metals }\end{array}$ & $\begin{array}{l}\text { Media regeneration } \\
\text { requires chemical } \\
\text { usage, generation of } \\
\text { solid waste }\end{array}$ \\
\hline Ion-exchange & $\begin{array}{l}\text { Removal of ions via ion } \\
\text { exchanging resins }\end{array}$ & $\begin{array}{l}\text { Able to remove ions, } \\
\text { boron removal, long } \\
\text { lifespan, possible } \\
\text { continuous } \\
\text { regeneration of resin, } \\
\text { efficient, mobile } \\
\text { treatment possible }\end{array}$ & $\begin{array}{l}\text { Pre- and post- } \\
\text { treatment may be } \\
\text { required, produce } \\
\text { effluent concentrate } \\
\text { (secondary waste), } \\
\text { high operating cost }\end{array}$ \\
\hline Media Filter & $\begin{array}{l}\text { Usage of filtering media } \\
\text { to filter contaminants }\end{array}$ & $\begin{array}{l}\text { Not affected by salinity, } \\
\text { able to remove heavy } \\
\text { metals, oil and grease, } \\
\text { and TOC }\end{array}$ & $\begin{array}{l}\text { Modification of } \\
\text { numerous units, } \\
\text { Media regeneration, } \\
\text { and generation of solid } \\
\text { waste (media) }\end{array}$ \\
\hline Gas floatation & $\begin{array}{l}\text { Removal of particles via } \\
\text { gas floatation towards } \\
\text { the surface. The } \\
\text { contaminants are then } \\
\text { skimmed }\end{array}$ & $\begin{array}{l}\text { Able to remove fine } \\
\text { particles, oil droplets } \\
\text { and volatile organics, } \\
\text { no moving parts, } \\
\text { higher efficiency } \\
\text { due to coalescence, } \\
\text { easy operation, }\end{array}$ & $\begin{array}{l}\text { Generation of a large } \\
\text { amount of } \\
\text { concentrated sludge } \\
\text { post-treatment for } \\
\text { sludge is expensive }\end{array}$ \\
\hline $\begin{array}{c}\text { Evaporation } \\
\text { Pond }\end{array}$ & $\begin{array}{l}\text { It relies on solar energy to } \\
\text { evaporate water and } \\
\text { concentrate waste }\end{array}$ & $\begin{array}{l}\text { Economical, the natural } \\
\text { process favors a warm } \\
\text { climate }\end{array}$ & $\begin{array}{l}\text { Sensitive towards } \\
\text { climate change } \\
\text { requires ample space } \\
\text { and is not suitable for } \\
\text { water reclamation }\end{array}$ \\
\hline $\begin{array}{l}\text { Freeze-thaw } \\
\text { evaporation }\end{array}$ & $\begin{array}{l}\text { It relies on cool } \\
\text { temperature to freeze } \\
\text { water into ice crystals } \\
\text { and thaw the ice and } \\
\text { produce pure water } \\
\text { while concentrating } \\
\text { contaminants }\end{array}$ & $\begin{array}{l}\text { Economical, no energy } \\
\text { required, the natural } \\
\text { process favors cold } \\
\text { climate }\end{array}$ & $\begin{array}{l}\text { Sensitive towards } \\
\text { climate change, lower } \\
\text { conversion efficiency, } \\
\text { long } \\
\text { operation cycle }\end{array}$ \\
\hline Electrodialysis & $\begin{array}{l}\text { Separations of ions } \\
\text { through a selective } \\
\text { membrane }\end{array}$ & $\begin{array}{l}\text { Able to separate ions, } \\
\text { efficient in low salinity } \\
\text { wastewater }\end{array}$ & $\begin{array}{l}\text { Membrane fouling and } \\
\text { uneconomical to treat } \\
\text { high salinity PW, high } \\
\text { treatment cost }\end{array}$ \\
\hline
\end{tabular}


Adsorption is commonly used to remove manganese, iron, total organic carbon (TOC), benzene, toluene, ethylene, and xylene (BTEX), oil, and more than $80 \%$ of heavy metals by using adsorbent (Colorado School of Mines, 2009). Examples of such adsorbents are activated carbon, organo-clay, activated alumina, and zeolites (Colorado School of Mines, 2009; Spellman, 2013). The system requires a vessel to hold the adsorbent media and a pump for backwashing to remove entrapped particulates. Plugging limits the adsorption, which reduces its efficiency (Fakhru'l-Razi et al., 2009). Chemical regeneration is applied to avoid media disposal (Colorado School of Mines, 2009; Spellman, 2013). This chemical regeneration can be considered a disadvantage since the use of chemicals requires chemical waste disposal, and disposal of the plugged media requires replacement and solid waste management.

An ion exchanger removes specific ions or compounds from a stream facilitated by exchanging a pre-saturated ion with the target ions on an ion exchanger resin. It effectively removes ions and metals via the usage of resins (Clifford, 1999). Besides that, ion exchange resin can remove boron from the permeate of RO (Nadav, 1999). While ion exchange has a long lifespan of $\sim$ eight years, like absorption, the resin also requires chemical regeneration (Fakhru'l-Razi et al., 2009).

Media filtration utilizes filtering media such as sand, gravel, anthracite, and walnut shell. Walnut shell is commonly used to treat PW since it is independent of salinity level (Igunnu \& Chen, 2014). Adewumi et al. (1992) outlined that a system must contain a $\mathrm{pH}$ adjustment to initiate the oxidation reaction to remove metals from PW via a sand filter. An aeration unit to increase the oxygen concentration for the said reaction, a solid separation unit with a sufficient retention time for solid settling, and finally, a sand filter to remove the fine solids. This system can remove $90 \%$ of PW's iron, oil, grease, and TOC. The drawback of this system includes media regeneration and solid waste management (Igunnu \& Chen, 2014).

Gas/air floatation is also used to treat PW. It uses aeration or fine gas bubbles to separate suspended particles that cannot be separated via primary sedimentation. It is done by injecting gas into the feed, in which suspended particles and oil droplets later attach to the air bubbles to form bubble-particle agglomerate and rise to the surface that can be skimmed off (Casaday, 1993). It can remove small particles (3$25 \mu \mathrm{m}$ ) if coagulation is used as pre-treatment (Colorado School of Mines, 2009). It can also remove grease and oil, natural organic matters, and volatile organics. However, the drawback of gas floatation is that it cannot remove oil-soluble constituents from the feed (Colorado School of Mines, 2009). Solid waste disposal is necessary from the sludge generated, and it poses high OPEX (\$0.60/ $\mathrm{m}^{3}$ of PW) (Casaday, 1993).

The evaporation pond evaporates water from the PW via solar energy as a heat source to drive the evaporation. It thus favors a warm and dry climate. It is considered economical and used to treat PW both on and offsite (Igunnu \& Chen, 2014a). However, it requires ample space (Velmurugan \& Srithar, 2008). Moreover, it is a disadvantage where water recovery is concerned (Igunnu \& Chen, 2014a).

Freeze-thaw evaporation involves the freezing, thawing, and evaporation of the feed. It involves cooling the feed to allow only water to be frozen into an ice crystal. The process will separate the water from the unfrozen and highly concentrated liquid. The ice is then removed and melted to obtain clean water. It is reported that around $50 \%$ of water can be recovered during winter (Igunnu \& Chen, 2014a). This method can effectively remove up to $90 \%$ of heavy metals, TDS, volatile organics, TSS, and total recoverable hydrocarbon in PW (Boysen et al., 1999). However, it can only work 
for a limited number of days at which temperature is below freezing, and waste disposal is essential since it generates highly concentrated brine and oily waste (Igunnu \& Chen, 2014).

Electro-dialysis (ED) used both electrochemistry and desalination. It separates dissolved ions from the feedthrough an ion-permeable membrane that can selectively transport ions of opposite charge while rejecting ions of similar charge (Arthur et al., 2005). While this system works best to treat PW with low TDS, it is unlikely to be costeffective to treat relatively high salinity and concentrated PW (Sirivedhin et al., 2004). Since this system also utilizes membrane technology, it is also susceptible to membrane fouling (Colorado School of Mines, 2009).

\section{MEMBRANE SEPARATION}

Conventional PW treatments face a few challenges such as high costs, require chemical usage (i.e., for regeneration of media), media replacement. Some are sensitive to climate change, while others may generate secondary waste. In most cases, a train of treatment process also requires the polishing step of the membrane-based process to polish the treated water to meet the discharge requirements, particularly for removing dissolved oil. Membrane separation technologies have thus become critical to accompany the conventional treatment methods. The most common membrane processes applied for PW treatment are pressure-driven, including MF, $\mathrm{UF}, \mathrm{NF}$, and RO. These membrane processes rely on differential pressure as a driving force to facilitate (the convective or diffusive) mass transport across the membrane. The permeability of this membrane and the size of rejected particles decrease from MF $>$ UF $>$ NF $>$ RO (Fakhru'l-Razi et al., 2009). MF has the largest pore $(0.1-3 \mu \mathrm{m})$ and is commonly used to remove suspended solids, while UF (pore size of $0.01-0.1 \mu \mathrm{m}$ ) is mainly used to remove macromolecules (Fakhru'l-Razi et al., 2009; Igunnu \& Chen, 2014). Both MF and UF operate at low pressures of fewer than 5 bars, but they cannot remove salts or TDS from water (Colorado School of Mines, 2009). NF is selective towards multivalent ions rather than univalent ions, while $\mathrm{RO}$ separates dissolved solutes and ionic compounds (Madaeni, 1999).

Though the pressure-driven membrane is widely used in industries, they are prone to organic fouling (E.-S. Kim et al., 2011; Sutzkover-Gutman \& Hasson, 2010). The usage of high pressure renders the fouling effect irreversible via excessive cake layer compaction (Lee et al., 2010a). Moreover, depending on the region, the constituent of PW may contain a high level of salinity to a level economically untenable by the RO process (Al-Furaiji, 2016). Pressure-driven membranes are also sensitive to the chemicals and contaminants in the feed, which could compromise the membrane functionality and surface chemistry (Coday et al., 2014).

\section{FUNDAMENTAL OF FORWARD OSMOSIS}

For water and wastewater treatment, $\mathrm{RO}$ is more popular than emerging $\mathrm{FO}$. FO process is driven by osmotic pressure to facilitate mass transport. In principle, FO naturally transports water from a phase with a low solute concentration to a phase with a higher solute concentration through a semi-permeable FO membrane. An FO system must consist of a feed stream that is the PW and a draw stream, a concentrated stream that provides the osmotic difference. In FO, a membrane is directly in contact with both solutions to selectively facilitate selective mass transport. 
$\mathrm{RO}$ caters to desalination by concentrating the feed to form the brine solution while producing pure water. On the other hand, FO results in dewatering the feed (concentrating the feed) and diluting the DS. Another process related to FO is called Pressure Retarded Osmosis (PRO) (Sourirajan \& Agrawal, 1969). PRO utilizes the differential osmotic pressure between two solutions $(\Delta \Pi)$ to pressurize the product stream that can later be converted to generate electricity (Cath et al., 2006). Figure 1 illustrates the differences in $\mathrm{FO}, \mathrm{RO}$, and $\mathrm{PRO}$ and illustrates the directions of permeate flows.

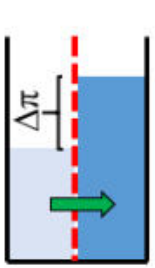

FO

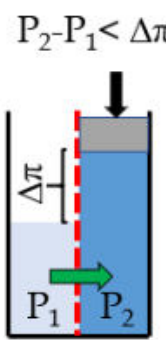

PRO

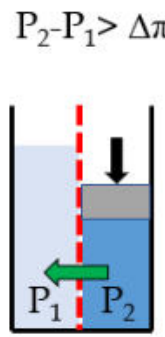

$\mathrm{RO}$

\section{$\square$ Fresh water \\ Saline water \\ -- Membrane Layer}

Figure 1. Simplified diagram for FO, PRO, and RO mechanism based on differential pressure and osmotic pressure

FO relies on the osmotic power of the DS. The higher the osmotic power of DS (more concentrated DS), the higher the fluxes. In comparison with $\mathrm{RO}$, the water from the seawater is transported to the fresh waterside. It uses external hydraulic pressure to force the desalination to process. The used hydraulic pressure $(\mathrm{P})$ must be enough to overcome the osmotic pressure $\Delta \Pi$ between the two solutions. The effort to overcome the $\Delta \Pi$ makes $\mathrm{RO}$ an energy-intensive process.

FO has a variety of advantages. Firstly, FO does not require any external pressure, and if required, it is only for recirculation, thus making it low in energy footprint. In fact, for a once-through system that does not require DS recovery, FO is ultimately more energy-efficient than RO (Coday et al., 2014; Cornelissen et al., 2008), one of the main reasons to conduct the current works. FO also displays an impressive performance in separation. FO efficiently removes TDS from a complex solution and demonstrates high salt rejection (at 96\%) (Coday et al., 2014). It is also reported that FO rejects a high amount of contaminants despite operating in ambient conditions (Cornelissen et al., 2008).

Moreover, FO also has a lower fouling propensity, particularly when treating synthetic feeds (Achilli et al., 2009; Lee et al., 2010) due to the absence of high hydraulic pressure, which renders the fouling to be more reversible (Lee et al., 2010a). Therefore, FO has a more straightforward cleaning method than pressure-driven membrane (Hoover et al., 2011). FO cleanings include osmotic backwashing and manipulating cross-flow velocities. FO can be used as a stand-alone process with the above advantages and potentially does not require any pre-treatment, unlike $\mathrm{NF}$ and $\mathrm{RO}$ (Coday et al., 2014a). FO can also work under conditions untenable by RO, i.e., extremely high salinity wastewater, requiring too high pressure for desalination (Al- 
Furaiji, 2016). FO has proven to work well despite a low flux of $1 \mathrm{~L} / \mathrm{m}^{2} \mathrm{~h}$ when ammonia-carbon dioxide $\left(\mathrm{NH}_{3}-\mathrm{CO}_{2}\right)$ is $\mathrm{DS}$ and $4.5 \mathrm{~L} / \mathrm{m}^{2} \mathrm{~h}$ using $\mathrm{MgCl}_{2}$ as DS.

Despite those advantages, FO also has several setbacks. One is a low water flux (Seppälä \& Lampinen, 2004). Another shortcoming of FO is the existence of reverse solute flux (RSF), owning to CP (Hancock \& Cath, 2009). For specific feeds, including $\mathrm{PW}, \mathrm{FO}$ is also susceptible to membrane fouling. This fouling would also decline the permeate flux. However, the fouling is expected to be less severe than in NF or RO (Achilli et al., 2009b; Lee et al., 2010a; Sutzkover-Gutman \& Hasson, 2010).

\section{FORWARD OSMOSIS IN PRODUCED WATER TREATMENT}

Because of the attractive advantages, FO has been explored for many applications, including the treatment of PW. A few parameters are involved in the literature, namely feed solution, DS, and the type of membranes.

There are many contaminants in PW, including chemicals additives and stable oil emulsion, which hinder the performance of FO. However, others use oily water emulsion to mimic PW treatment (Duong \& Chung, 2014; Zhang et al., 2014a). For preparing synthetic PW feed, Duong \& Chung (2014) uses a mixture of soybean oil, Tween 80, and water, while Zhang et al. (2014), mixes petroleum, Tween 80 , acetic acid, and sodium chloride, $\mathrm{NaCl}$. Both show high $\mathrm{FO}$ water flux. However, the foulant present in actual PW is more complex. If the feed is highly concentrated, the permeate flux decline would be severe. For example, Al-Furaiji, (2016) treated hyper-saline PW, which requires a stronger DS to promote sufficient driving force of FO.

Another issue with FO for PW treatment is the selection of the DS. Types and concentrations of DS affect the FO performances. $\mathrm{NaCl}$ or $\mathrm{RO}$ brine has been used as DSs. On the other hand, seawater contains numerous particles and microorganisms that foul the membrane (Lutchmiah et al., 2014). Different DSs had been tested by AlFuraiji, (2016), namely magnesium chloride $\left(\mathrm{MgCl}_{2}\right)$ and ammonia-carbon dioxide $\left(\mathrm{NH}_{3}-\mathrm{CO}_{2}\right)$, to enhance the flux. It was found that the fluxes obtained were 1 and 4.5 $\mathrm{L} / \mathrm{m}^{2} \mathrm{~h}$ when using $\mathrm{NH}_{3}-\mathrm{CO}_{2}$ and $\mathrm{MgCl}_{2}$ as $\mathrm{DSs}$, respectively. However, when using $\mathrm{NH}_{3}-\mathrm{CO}_{2}$, it raises $\mathrm{pH}$-value and promotes scaling, while $\mathrm{MgCl}_{2}$ is seen less viable due to problems in DS regeneration.

Membrane materials also affect the performance of FO. Generally, the desired FO membrane should have the following characteristics: 1) a dense and thin active layer (AL) for high solute rejection, 2) thin, hydrophilic support layer (SL) with mechanical stability for long term operation and internal concentration polarization reduction and 3) high hydrophilicity and low fouling propensity (Lutchmiah et al., 2014).

Cellulose triacetate (CTA) membrane is widely used in FO due to its high resistance towards thermal, chemical, and biological degradation (Mulder, 1996). Moreover, it is less prone to absorptive fouling, making it attractive to treat challenging feeds (Lutchmiah et al., 2014; Thorsen, 2004). Thin-film composite (TFC) membranes are made of a very thin active layer (i.e., polyamide, PA) on top of a polysulfone porous layer deposited on a non-woven support sheet (Lau et al., 2012). In comparison, the TFC membrane has superior properties to CTA in terms of permeability and rejection (Bell et al., 2017a; Chowdhury et al., 2017; Klaysom et al., 2013; Li et al., 2018). The porous support layer of the TFC membrane also affects CP (Li et al., 2018). However, TFC suffers from higher RSF than CTA membrane (Coday et al., 2014), owning its lower selectivity (Li et al., 2018). Furthermore, the TFC membrane had a higher water 
permeability and lesser salt permeability than the CTA membrane (Li et al., 2018) because it is more prone to adsorptive fouling than CTA (Lutchmiah et al., 2014; Thorsen, 2004). However, the adsorptive foulant on TFC is reversible and could be easily removed.

Another study explores the effect of membrane type. The most common one is the flat sheet, followed by hollow fibre (HF). HF offers higher packing density, resulting in high productivity per unit volume, and can operate without using a spacer. HF was reported to have 1.38 times higher permeate flux than flat sheets (Minier-Matar et al., 2016). HF could also reduce the effect of RSF to $\leq 3 \mathrm{mmol} / \mathrm{m}^{2} \mathrm{~h}$ compared to a flat sheet. Table 2 shows the summary of PW treatment using FO.

Table 2. Comparative study on PW treatment using FO

\begin{tabular}{|c|c|c|c|c|}
\hline Feed & Draw & Membrane & Result & Reference \\
\hline PW & $\mathrm{NaCl}$ & CTA & $14 \mathrm{~L} / \mathrm{m}^{2} \mathrm{~h}-2 \mathrm{~L} / \mathrm{m}^{2} \mathrm{~h}$ & $\begin{array}{l}\text { (Hickenbottom } \\
\text { et al., 2013b) }\end{array}$ \\
\hline $\begin{array}{l}\text { Oily } \\
\text { water } \\
\text { emulsion }\end{array}$ & $\mathrm{NaCl}$ & $\begin{array}{l}\text { TFC (FO-MD } \\
\text { Hybrid) }\end{array}$ & $26.7 \pm 3.5 \mathrm{~L} / \mathrm{m}^{2} \mathrm{~h}$ & $\begin{array}{l}\text { (Zhang et al., } \\
2014 b \text { ) }\end{array}$ \\
\hline $\begin{array}{l}\text { Oily } \\
\text { water } \\
\text { emulsion }\end{array}$ & $\mathrm{NaCl}$ & PAN-TFC & $16.5 \pm 1.2 \mathrm{~L} / \mathrm{m}^{2} \mathrm{~h}$ & $\begin{array}{l}\text { (Duong \& } \\
\text { Chung, 2014) }\end{array}$ \\
\hline PW & $\mathrm{NaCl}$ & CTA, TFC & $\begin{array}{l}7.9 \pm 0.3 \mathrm{~L} / \mathrm{m}^{2} \mathrm{~h}(\mathrm{CTA}) \\
11 \pm 1.2 \mathrm{~L} / \mathrm{m}^{2} \mathrm{~h}(\mathrm{TFC})\end{array}$ & $\begin{array}{l}\text { (Bell et al., } \\
\text { 2017b) }\end{array}$ \\
\hline PPW & $\mathrm{NaCl}$ & TFC (Flat sheet) & $13.5 \mathrm{~L} / \mathrm{m}^{2} \mathrm{~h}$ & $\begin{array}{l}\text { (Minier-Matar } \\
\text { et al., 2015) }\end{array}$ \\
\hline PW & $\mathrm{NaCl}$ & $\begin{array}{l}\text { TFC [Flat sheet } \\
\text { (FS) and hollow } \\
\text { fiber }(\mathrm{HF})]\end{array}$ & $\begin{array}{l}13 \mathrm{~L} / \mathrm{m}^{2} \mathrm{~h} \text { (Flat sheet) } \\
\text { and } 18 \mathrm{~L} / \mathrm{m}^{2} \mathrm{~h}(\mathrm{HF})\end{array}$ & $\begin{array}{l}\text { (Minier-Matar } \\
\text { et al., 2016) }\end{array}$ \\
\hline PW & $\mathrm{NaCl}$ & $\begin{array}{l}\text { CTA and TFC- } \\
\text { PA }\end{array}$ & $3 \mathrm{~L} / \mathrm{m}^{2} \mathrm{~h}$ & $\begin{array}{l}\text { (Coday et al., } \\
\text { 2016) }\end{array}$ \\
\hline $\begin{array}{l}\text { High } \\
\text { salinity } \\
\text { PW }\end{array}$ & $\begin{array}{l}\mathrm{NH}_{3}-\mathrm{CO}_{2} \\
\text { and } \mathrm{MgCl}_{2}\end{array}$ & CTA & $\begin{array}{l}1 \mathrm{~L} / \mathrm{m}^{2} \mathrm{~h}\left(\mathrm{NH}_{3}-\right. \\
\left.\mathrm{CO}_{2}\right), 4.5 \mathrm{~L} / \mathrm{m}^{2} \mathrm{~h} \\
\left(\mathrm{MgCl}_{2}\right)\end{array}$ & $\begin{array}{l}\text { (Al-Furaiji, } \\
\text { 2016) }\end{array}$ \\
\hline
\end{tabular}

\section{MEMBRANE FOULING MECHANISM}

Membrane fouling occurs when the feed solution contains a constituent attached and clogs the membrane pores. This phenomenon is the primary setback in membrane technology and is more severe in a pressure-driven membrane. Since the content of PW consists of high dissolved organic and inorganic compounds, colloidal matters, and microorganisms, fouling would be more prominent. (Alzahrani et al., 2013). Fouling can be categorized based on the nature of the materials, namely organic fouling, inorganic fouling, and biofouling.

Organic fouling is the attachment of organics foulant on the surface of the membrane. The foulant may be hydrophobic, transphilic, and hydrophilic. Examples 
of organic foulant are humic acid, polysaccharides, and alginic acids, to name a few. In contrast, inorganic foulant such as $\mathrm{CaSO}_{4}$ and $\mathrm{CaCO}_{3}$ result from the accumulation and deposition of salts on the membrane surface (Chun et al., 2017). Biofouling can be defined as the deposition of microorganisms, such as bacteria or algae on the membrane surface. The bio-foulant can accumulate and grow on the membrane surface, thus forming a biofilm. The accumulation of such foulant would increase the resistance for permeation and thus lowering permeate flux (Nawi et al., 2020).

Regardless, the foulant restricts permeate's mass transport by blocking the pore (either through complete, standard, or intermediate pore blockings) and eventually accumulates into cake formation (Nourbakhsh et al., 2014; F. Wang \& Tarabara, 2008). Figure 2(a-d) are the common pore-blocking mechanism found in a porous membrane (Abd Halim et al., 2021). For membrane with a tiny pore, i.e., FO, cake formation, Figure 2(e) is most likely to happen. The mechanism for complete pore blocking (a) involves a larger particle relative to the membrane pore size. The particle eventually reaches the pore without superimposing each other.

In contrast, standard blocking (b) involves depositing smaller particles relative to the membrane pore size within the pore to complete pore blocking. This blocking causes the effective pore volume to decrease hence hindering permeance. Over time, particles can be deposited onto other particles. Particles deposited onto the already blocked particle via complete blocking (a) are intermediate pore blocking (c). Eventually, the particles form a film known as cake formation due to particles accumulation overtime on the membrane surface. Without proper fouling control, the particles would continue to deposit onto each other, making the cake layer thicker.

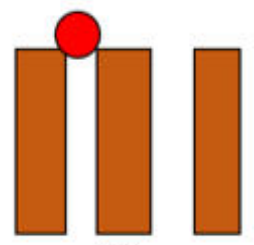

(a)

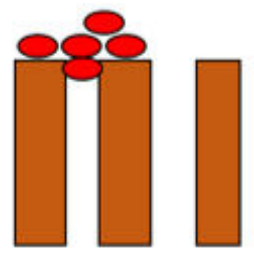

(c)

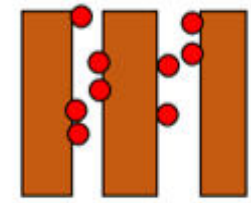

(b)

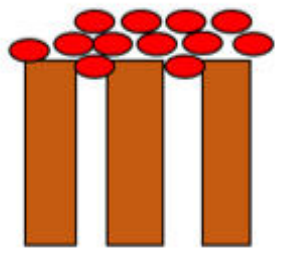

(d)

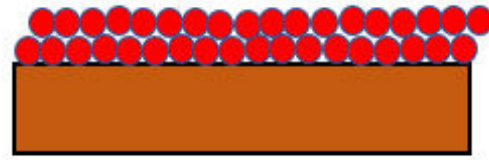

(e)

Figure Error! No text of specified style in document.. Pore blocking mechanism; (a) complete, (b) standard, (c) intermediate pore blocking, and (d) cake formation on the porous membrane surface. They were retrieved from (Abd Halim et al., 2021). The cake formation (e) is likely to happen to a dense, asymmetric membrane, i.e., FO.

Membrane fouling diminishes overall membrane performance during treatment of PW. The foulant in PW consists of organics and inorganics, typically characterized by TOC of 33-292 mg/L and TDS at 2090-181,600 mg/L (Alzahrani et al., 2013). As a result, $\mathrm{NF}$ and $\mathrm{RO}$ membrane typically require rigorous pre-treatment when dealing with PW (Coday et al., 2014a). The pre-treatment often involves multiple processes 
that escalate the costs (OPEX and CAPEX). Despite being effective in maintaining membrane performance, chemical cleaning might generate harmful products such as trihalomethanes (THMs) and, depending on the chemical used, other potential carcinogens (Chun et al., 2017). Also, the usage of chemical agents would degrade the membrane hence shortening its lifespan (Flemming et al., 1997).

\section{MEMBRANE FOULING CONTROL}

Although FO has a lower fouling tendency than pressure-driven membranes, it is still not free from fouling. Therefore, there is a need to address membrane fouling control, especially when handling highly polluted feeds. This section provides an overview of current membrane FO fouling control and is summarised in Table 3.

\section{Osmotic Backwashing}

Osmotic backwashing involves water flow from the permeate side to the feed side. The water flows from feed to the DS in a normal FO mode. In osmotic backwashing, the flow of water is reversed by exchanging the placement of the feed and DS. This yields a reverse-flow of water which helps to detach the foulant. A study by (Yu et al., 2016) investigates the effectiveness of osmotic backwashing by using more concentrated feed while maintaining $3 \mathrm{M}$ of $\mathrm{NaCl}$ as $\mathrm{DS}$. The results show up to $99.9 \%$ of initial flux recovery.

Another study by Kim et al. (2012) investigated the mechanism of osmotic backwashing. They found several factors that affect the cleaning efficacy. These factors include foulant types (including its size), membrane orientation, and backwashing conditions. They found that alginate foulant was more easily removed than humic acid due to greater hydrophobicity. Fouling was very severe for particulate foulant (e.g., silica particles), enhanced by cake enhanced concentration polarisation (CECP). The flux then could not be fully recovered via osmotic backwashing. Generally, active layer facing feed solution (AL-FS) exhibits greater fouling resistance than active layer facing draw solution (AL-DS) (C. Kim et al., 2012; Tang et al., 2010). This phenomenon can be explained due to the ineffectiveness of shear force exerted to remove foulant inside the porous SL during osmotic backwashing. Osmotic backwashing can remove foulant thanks to the reverse flow of water. It eliminates the usage of chemicals that may alter the membrane's surface chemistry. The effectiveness of osmotic backwashing also depends on several factors, as mentioned earlier. This method cannot be performed as filtration operation is undergoing, its requirement to switch feed placement and DS on the opposite side of the membrane.

\section{Ultrasound}

Ultrasound cleaning employs ultrasound waves to remove foulant. Transmission of such waves is through a transducer. The mechanism of ultrasound introduces acoustic cavitation (Leong et al., 2011) that induces shear stress to remove the foulant. Ultrasound cleaning has been vastly explored on a pressure-driven membrane but less on the FO membrane.

A study on the application of ultrasound cleaning found that a lower frequency of ultrasonic radiation $(28 \mathrm{kHz})$ could enhance the permeability of MF and UF membrane and provide better cleaning efficiency compared to a higher frequency $(45 \mathrm{kHz}$ and $100 \mathrm{kHz})$ (Kobayashi et al., 2003). Other studies were done 
for activated sludge (Lee et al., 2017; Nguyen et al., 2015) which showed enhancement of water flux via ultrasound-assisted FO at $40 \mathrm{kHz}$. Another study investigates the effect of power intensity on the permeate flux (Lamminen et al., 2004). They found that the permeate flux increases with increasing power intensity at a constant frequency $(625 \mathrm{kHz}$ for $5 \mathrm{~s})$. The increase is due to an increase in cavitation and turbulence resulting from the increased implosion of the bubbles. This study also reveals that low frequency is more efficient because the intensity of bubbles collapse is greater than in high frequency, even if the high frequency has more cavitation per time but produces weaker implosion (Lamminen et al., 2004). The ultrasound cleaning method could also increase its efficiency when combined with forwarding water washing (Kobayashi et al., 2003; Nguyen et al., 2015). It provides the system with an enhanced cross-flow velocity to scour the foulant.

The main advantage of ultrasound includes its ability to be used during filtration. The system can be combined with other methods to maximize its cleaning efficiency, namely forward water flushing (Kobayashi et al., 2003; Nguyen et al., 2015). This system's drawback lies in its complexity, ultrasound energy provided towards the membrane surface is not uniform (Lamminen et al., 2004). It may potentially damage the membrane structure integrity (Masselin et al., 2001).

\section{Chemical Cleaning}

Chemical cleaning employs chemicals, either acidic, basic, or oxidants solution to remove the foulant. The membranes are soaked in a cleaning solution at a certain concentration and period, which will then be washed either forward or backward, flushing to remove the foulant (Ahmad et al., 2012).

Generally, acidic is used to effectively remove organic fouling via hydrolysis and solubilization. At the same time, basic is effective in removing inorganic foulant via neutralization, and double decomposition reaction and oxidants remove both organic and biofouling through oxidation (X. Wang et al., 2017). Furthermore, metal chelating agents such as disodium ethylene-diamine-tetraacetate (EDTA-2Na) effectively break down the biofouling structure by removing the divalent cation, a bridging agent, in the foulant (X. Wang et al., 2017). Sodium hypochlorite $(\mathrm{NaClO})$ is commonly used in chemical cleaning. It is important to note that chemicals can potentially damage the membrane (Soice et al., 2003).

Concentration and cleaning period play essential roles. Excessive concentration or prolonged exposure to chemical cleaning would damage the membrane. A recent study investigates the effectiveness of several cleaning agents and claims that hydrogen peroxide $\left(\mathrm{H}_{2} \mathrm{O}_{2}\right)$ is the most effective, with an almost $100 \%$ flux recovery. Nonetheless, $\mathrm{H}_{2} \mathrm{O}_{2}$ without proper control on concentration and cleaning period can damage the membrane ( $X$. Wang et al., 2017). Hence, an optimal condition of $0.5 \%$ concentration and $6 \mathrm{~h}$ of cleaning period was proposed with a flux recovery up to $95 \%$.

Chemical cleaning can effectively remove foulant and has been proven to achieve high flux recovery (X. Wang et al., 2017). However, the cleaning procedure cannot be done simultaneously during operation. Furthermore, chemical cleaning risks damaging the membrane before knowing the foulant type. A proper cleaning agent with appropriate concentration and cleaning period 
needs to be addressed beforehand. Moreover, chemicals complicate the filtration process as it generates secondary waste.

\section{Air Sparging}

Air sparging is done by injection of air directly into the module during filtration. It is an additional alternative method to reduce chemical cleaning frequencies. It is also considered a standard approach to reduce membrane fouling and concentration polarisation in various systems (e.g., membrane bioreactor) (Psoch \& Schiewer, 2006; Xia et al., 2013). By injecting air inside the system, air bubbles will form and scour the foulant on top of the membrane surface via hydrodynamic shear stress provided by the air bubbles (Ducom et al., 2002; Psoch \& Schiewer, 2006). Consequently, flux is enhanced through the removal of foulant.

Fouling control via air sparging can be affected by the sparging condition, including air bubble size and rate of injection or frequency and the shear rate induced on the membrane surface (Chan et al., 2007; Cui et al., 2003). Generally, the higher the bubble size, frequency, and shear rate, the more effective the cleaning are (Jankhah \& Bérubé, 2014).

Air bubbling offer in situ process during filtration. It also helps to reduce the frequency of chemical cleaning. Because of its simplicity, it can be integrated into a system quickly. Air bubbling reduces CP, in which FO still suffers (Psoch \& Schiewer, 2006; Xia et al., 2013). However, air sparging has a few limitations. According to Bilad et al. (2012), it is not easy to maintain intense air bubbles with the membrane surface. The air bubbles tend to reside in the center of the membrane module or the area of influence by the air bubbles. The impact of air sparging reaches a plateau at a specific air supply rate. Recently, modifications of membrane panels in combination with aeration could impose some fouling control in FO by panel inclination (Hizam et al., 2021) and air bubble assisted membrane vibration (Razak et al., 2020). Both can also be applied for PW treatment using the FO process.

On top of limiting membrane fouling, research aspects in system configuration still lack FO for PW treatment. FO can be combined with other processes to maximize the system throughput under minimum costs (Wibisono \& Bilad, 2020). For example, FO and membrane distillation can be combined using the process intensification approach for PW treatment (Mat Nawi et al., 2020). Fouling-resistant FO membrane can still be developed by tailoring its properties suitable for PW treatment, such as aquaporin-based FO membrane (Chun et al., 2018). Accurate characterization method (Bilad et al., 2018) and assessment under the large-scale system (Bilad, 2017) are required to accurately judge the membrane and system performances.

Table 3. Summary of FO fouling control/membrane cleaning

\begin{tabular}{llll}
\hline $\begin{array}{l}\text { Cleaning } \\
\text { Method }\end{array}$ & Description & Advantage & Disadvantage \\
\hline $\begin{array}{l}\text { Osmotic } \\
\text { Backwashing }\end{array}$ & $\begin{array}{l}\text { The reverse flow } \\
\text { of water from } \\
\text { permeate to feed } \\
\text { side due to }\end{array}$ & $\begin{array}{l}\text { Simple eliminates the } \\
\text { usage of chemicals } \\
\text { during cleaning }\end{array}$ & $\begin{array}{l}\text { It cannot be } \\
\text { performed } \\
\text { during the } \\
\text { filtration process. } \\
\text { Cleaning }\end{array}$ \\
\hline
\end{tabular}




\begin{tabular}{|c|c|c|c|}
\hline $\begin{array}{l}\text { Cleaning } \\
\text { Method }\end{array}$ & Description & Advantage & Disadvantage \\
\hline & $\begin{array}{l}\text { concentration } \\
\text { difference }\end{array}$ & & $\begin{array}{l}\text { efficiency } \\
\text { decrease } \\
\text { overtime }\end{array}$ \\
\hline Ultrasound & $\begin{array}{l}\text { Removal of } \\
\text { foulant via } \\
\text { sonification }\end{array}$ & $\begin{array}{l}\text { Can be performed } \\
\text { while filtration } \\
\text { process is } \\
\text { undergoing, } \\
\text { eliminates usage of } \\
\text { chemicals during } \\
\text { cleaning }\end{array}$ & $\begin{array}{l}\text { Complex, non- } \\
\text { uniform } \\
\text { sonification can } \\
\text { potentially } \\
\text { damage the } \\
\text { membrane due to } \\
\text { violent } \\
\text { cavitation, may } \\
\text { require } \\
\text { additional } \\
\text { cleaning methods } \\
\text { to improve } \\
\text { efficiency }\end{array}$ \\
\hline $\begin{array}{l}\text { Chemical } \\
\text { Cleaning }\end{array}$ & $\begin{array}{l}\text { Applying } \\
\text { chemicals directly } \\
\text { to the membrane } \\
\text { at a specific } \\
\text { concentration and } \\
\text { period }\end{array}$ & $\begin{array}{l}\text { High cleaning } \\
\text { efficiency }\end{array}$ & $\begin{array}{l}\text { It cannot be } \\
\text { performed } \\
\text { during the } \\
\text { filtration process, } \\
\text { can potentially } \\
\text { damage the } \\
\text { membrane, } \\
\text { generation of } \\
\text { secondary waste }\end{array}$ \\
\hline Air Sparging & $\begin{array}{l}\text { Injection of air } \\
\text { directly into the } \\
\text { membrane } \\
\text { module during } \\
\text { filtration }\end{array}$ & $\begin{array}{l}\text { Simple eliminates the } \\
\text { usage of chemicals } \\
\text { during cleaning, able } \\
\text { to reduce } \\
\text { concentration } \\
\text { polarization effect }\end{array}$ & $\begin{array}{l}\text { Difficult to } \\
\text { maintain air } \\
\text { bubble contact } \\
\text { with the } \\
\text { membrane }\end{array}$ \\
\hline
\end{tabular}

\section{CONCLUSION}

Indeed, PW is complicated to treat even with conventional methods as the required treatment cost is high, and some treatment requires an extra polishing step to meet the standard discharge requirement. FO was reviewed to investigate its effectiveness in PW treatment as an alternative. Although FO treated PW with minimal fouling, it is not free from the fouling effect. Osmotic backwashing, ultrasound, chemical cleaning, and air sparging are reviewed as membrane fouling control techniques. Depending on the type of operation, each method has its pros and cons and can recover FO performance.

\section{ACKNOWLEDGMENT}

Authors thank Universiti Teknologi PETRONAS for providing a general Assistance Master Degree Scholarship for Shafiq Mohd Hizam. 


\section{REFERENCES}

Abd Halim, N. S., Wirzal, M. D. H., Hizam, S. M., Bilad, M. R., Nordin, N. A. H. M., Sambudi, N. S., Putra, Z. A., \& Yusoff, A. R. M. (2021). Recent Development on Electrospun Nanofiber Membrane for Produced Water Treatment: A review. Journal of Environmental Chemical Engineering, 9(1), 104613. https:// doi.org/10.1016/j.jece.2020.104613

Achilli, A., Cath, T. Y., Marchand, E. A., \& Childress, A. E. (2009a). The forward osmosis membrane bioreactor: A low fouling alternative to MBR processes. Desalination, 239(1), 10-21. https://doi.org/10.1016/j.desal.2008.02.022

Achilli, A., Cath, T. Y., Marchand, E. A., \& Childress, A. E. (2009b). The forward osmosis membrane bioreactor: A low fouling alternative to MBR processes. Desalination, 239(1), 10-21. https://doi.org/10.1016/j.desal.2008.02.022

Adewumi, M. A., Erb, J. E., \& Watson, R. W. (1992). Initial Design Considerations for a Cost Effective Treatment of Stripper Oil Well Produced Water. In Produced Water (pp. 511-522). Springer, Boston, MA. https://doi.org/10.1007/978-14615-2902-6_40

Ahmad, A. L., Lah, N. F. C., Ismail, S., \& Ooi, B. S. (2012). Membrane Antifouling Methods and Alternatives: Ultrasound Approach. Separation $\mathcal{E}$ Purification Reviews, 41(4), 318-346. https:/ / doi.org/10.1080/15422119.2011.617804

Al-Furaiji, M. (2016). Hyper-saline produced water treatment for beneficial use. https:/ / doi.org/10.3990/1.9789036541565

Alzahrani, S., Mohammad, A. W., Hilal, N., Abdullah, P., \& Jaafar, O. (2013). Identification of foulants, fouling mechanisms and cleaning efficiency for NF and RO treatment of produced water. Separation and Purification Technology, 118(Supplement C), 324-341. https:/ / doi.org/10.1016/j.seppur.2013.07.016

Arthur, J., Langhus, B., \& Patel, C. (2005). Technical summary of oil and gas produced water treatment technologies (p. 53). ALL Consulting, LLC.

Bell, E. A., Poynor, T. E., Newhart, K. B., Regnery, J., Coday, B. D., \& Cath, T. Y. (2017a). Produced water treatment using forward osmosis membranes: Evaluation of extended-time performance and fouling. Journal of Membrane $\begin{array}{lll}\text { Science, } & \text { 525(Supplement } & \text { C), 77-88. }\end{array}$ https:// doi.org/10.1016/j.memsci.2016.10.032

Bell, E. A., Poynor, T. E., Newhart, K. B., Regnery, J., Coday, B. D., \& Cath, T. Y. (2017b). Produced water treatment using forward osmosis membranes: Evaluation of extended-time performance and fouling. Journal of Membrane $\begin{array}{lll}\text { Science, } & \text { 525(Supplement } & \text { C), }\end{array}$ https:/ / doi.org/10.1016/j.memsci.2016.10.032

Bilad, M. R. (2017). Module-scale simulation of forward osmosis module-part B: Modified Spiral-Wound. Indonesian Journal of Science and Technology, 2(2), 211. https:// doi.org/10.17509/ijost.v2i2.7998

Bilad, M. R., Mezohegyi, G., Declerck, P., \& Vankelecom, I. F. J. (2012). Novel magnetically induced membrane vibration (MMV) for fouling control in membrane bioreactors. Water Research, 46(1), 63-72. https:// doi.org/10.1016/j.watres.2011.10.026

Bilad, M. R., Qing, L., \& Fane, A. G. (2018). Non-linear least-square fitting method for characterization of forward osmosis membrane. Journal of Water Process Engineering, 25, 70-80. https://doi.org/10.1016/j.jwpe.2018.06.011 
Boysen, J., Harju, J., Shaw, B., Fosdick, M., Grisanti, A., \& Sorensen, J. (1999). The current status of commercial deployment of the freeze thaw evaporation treatment of produced water. SPE/EPA Exploration and Production Environmental Conference, Richardson, TX. https:/ / doi.org/10.2118/52700-MS

Çakmakce, M., Kayaalp, N., \& Koyuncu, I. (2008). Desalination of produced water from oil production fields by membrane processes. Desalination, 222(1), 176186. https://doi.org/10.1016/j.desal.2007.01.147

Casaday, A. L. (1993, January 1). Advances in Flotation Unit Design for Produced Water Treatment. SPE Production Operations Symposium. https:// doi.org/10.2118/25472-MS

Cath, T. Y., Childress, A. E., \& Elimelech, M. (2006). Forward osmosis: Principles, applications, and recent developments. Journal of Membrane Science, 281(1), 7087. https:// doi.org/10.1016/j.memsci.2006.05.048

Chan, C. C. V., Bérubé, P. R., \& Hall, E. R. (2007). Shear profiles inside gas sparged submerged hollow fiber membrane modules. Journal of Membrane Science, 297(1), 104-120. https:/ / doi.org/10.1016/j.memsci.2007.03.032

Chowdhury, M. R., Ren, J., Reimund, K., \& McCutcheon, J. R. (2017). A hybrid deadend/cross-flow forward osmosis system for evaluating osmotic flux performance at high recovery of produced water. Desalination, 421(Supplement C), 127-134. https:/ / doi.org/10.1016/j.desal.2016.08.021

Chun, Y., Mulcahy, D., Zou, L., \& Kim, I. S. (2017). A Short Review of Membrane Fouling in Forward Osmosis Processes. Membranes, 7(2). https:// doi.org/10.3390/membranes7020030

Chun, Y., Qing, L., Sun, G., Bilad, M. R., Fane, A. G., \& Chong, T. H. (2018). Prototype aquaporin-based forward osmosis membrane: Filtration properties and fouling resistance. Desalination, 445, 75-84. https:/ / doi.org/10.1016/j.desal.2018.07.030

Clifford, D. A. (1999). Chapter 9: Ion Exchange and Inorganic Adsorption. In Water Quality and Treatment: A Handbook of Community Water Supplies (5th ed.). McGraw-Hill.

Coday, B. D., Hoppe-Jones, C., Wandera, D., Shethji, J., Herron, J., Lampi, K., Snyder, S. A., \& Cath, T. Y. (2016). Evaluation of the transport parameters and physiochemical properties of forward osmosis membranes after treatment of produced water. Journal of Membrane Science, 499, 491-502. https:// doi.org/10.1016/j.memsci.2015.09.031

Coday, B. D., Xu, P., Beaudry, E. G., Herron, J., Lampi, K., Hancock, N. T., \& Cath, T. Y. (2014a). The sweet spot of forward osmosis: Treatment of produced water, drilling wastewater, and other complex and difficult liquid streams. Desalination, 333, 23-35.

Coday, B. D., Xu, P., Beaudry, E. G., Herron, J., Lampi, K., Hancock, N. T., \& Cath, T. Y. (2014b). The sweet spot of forward osmosis: Treatment of produced water, drilling wastewater, and other complex and difficult liquid streams. Desalination, 333(1), 23-35. https://doi.org/10.1016/j.desal.2013.11.014

Colorado School of Mines. (2009). Technical assessment of produced water treatment technologies. An Integrated Framework for Treatment and Management of Produced Water. RPSEA Project 07122-12, Colorado, 8-128.

Cornelissen, E. R., Harmsen, D., de Korte, K. F., Ruiken, C. J., Qin, J.-J., Oo, H., \& Wessels, L. P. (2008). Membrane fouling and process performance of forward 
osmosis membranes on activated sludge. Journal of Membrane Science, 319(1), 158-168. https:/ / doi.org/10.1016/j.memsci.2008.03.048

Cui, Z. F., Chang, S., \& Fane, A. G. (2003). The use of gas bubbling to enhance membrane processes. Journal of Membrane Science, 221(1), 1-35. https:/ / doi.org/10.1016/S0376-7388(03)00246-1

Ducom, G., Matamoros, H., \& Cabassud, C. (2002). Air sparging for flux enhancement in nanofiltration membranes: Application to $\mathrm{O} / \mathrm{W}$ stabilized and nonstabilized emulsions. Journal of Membrane Science, 204(1), 221-236. https:/ / doi.org/10.1016/S0376-7388(02)00044-3

Duong, P. H. H., \& Chung, T.-S. (2014). Application of thin film composite membranes with forward osmosis technology for the separation of emulsified oil-water. Journal of Membrane Science, 452(Supplement C), 117-126. https:/ / doi.org/10.1016/j.memsci.2013.10.030

Ebrahimi, M., Ashaghi, K. S., Engel, L., Willershausen, D., Mund, P., Bolduan, P., \& Czermak, P. (2009). Characterization and application of different ceramic membranes for the oilfield produced water treatment. Desalination, 245(1), 533540. https:/ / doi.org/10.1016/j.desal.2009.02.017

Fakhru'1-Razi, A., Pendashteh, A., Abdullah, L. C., Biak, D. R. A., Madaeni, S. S., \& Abidin, Z. Z. (2009a). Review of technologies for oil and gas produced water treatment. Journal of Hazardous Materials, 170(2), 530-551. https:/ / doi.org/10.1016/j.jhazmat.2009.05.044

Fakhru'l-Razi, A., Pendashteh, A., Abdullah, L. C., Biak, D. R. A., Madaeni, S. S., \& Abidin, Z. Z. (2009b). Review of technologies for oil and gas produced water treatment. Journal of Hazardous Materials, 170(2), 530-551. https:/ / doi.org/10.1016/j.jhazmat.2009.05.044

Fakhru'1-Razi, A., Pendashteh, A., Abdullah, L. C., Biak, D. R. A., Madaeni, S. S., \& Abidin, Z. Z. (2009c). Review of technologies for oil and gas produced water treatment. Journal of Hazardous Materials, 170(2), 530-551. https:// doi.org/10.1016/j.jhazmat.2009.05.044

Flemming, H.-C., Schaule, G., Griebe, T., Schmitt, J., \& Tamachkiarowa, A. (1997). Biofouling-The Achilles heel of membrane processes. Desalination, 113(2), 215-225. https:/ / doi.org/10.1016/S0011-9164(97)00132-X

Hancock, N. T., \& Cath, T. Y. (2009). Solute Coupled Diffusion in Osmotically Driven Membrane Processes. Environmental Science \& Technology, 43(17), 6769-6775. https:// doi.org/10.1021/es901132x

He, Y., \& Jiang, Z.-W. (2008). Technology review: Treating oilfield wastewater. Filtration $\mathcal{E}$ Separation, 45(5), 14-16. https://doi.org/10.1016/S00151882(08)70174-5

Hickenbottom, K. L., Hancock, N. T., Hutchings, N. R., Appleton, E. W., Beaudry, E. G., Xu, P., \& Cath, T. Y. (2013a). Forward osmosis treatment of drilling mud and fracturing wastewater from oil and gas operations. Desalination, 312(Supplement C), 60-66. https:/ / doi.org/10.1016/j.desal.2012.05.037

Hickenbottom, K. L., Hancock, N. T., Hutchings, N. R., Appleton, E. W., Beaudry, E. G., Xu, P., \& Cath, T. Y. (2013b). Forward osmosis treatment of drilling mud and fracturing wastewater from oil and gas operations. Desalination, 312(Supplement C), 60-66. https:// doi.org/10.1016/j.desal.2012.05.037

Hizam, S. M., Bilad, M. R., Nordin, N. A. H., Sambudi, N. S., Wirzal, M. D. H., Yusof, N., Klaysom, C., \& Jaafar, J. (2021). Inclined forward osmosis module system 
for fouling control in sustainable produced water treatment using seawater as draw solution. Journal of Water Process Engineering, 40, 101752. https:// doi.org/10.1016/j.jwpe.2020.101752

Hoover, L. A., Phillip, W. A., Tiraferri, A., Yip, N. Y., \& Elimelech, M. (2011). Forward with Osmosis: Emerging Applications for Greater Sustainability. Environmental Science \& Technology, 45(23), 9824-9830. https:/ / doi.org/10.1021/es202576h

Hutchings, N. R., Appleton, E. W., \& McGinnis, R. A. (2010, January 1). Making High Quality Frac Water out of Oilfield Waste. SPE Annual Technical Conference and Exhibition. https:// doi.org/10.2118/135469-MS

Igunnu, E. T., \& Chen, G. Z. (2014a). Produced water treatment technologies. International Journal of Low-Carbon Technologies, 9(3), 157-177. https:// doi.org/10.1093/ijlct/cts049

Igunnu, E. T., \& Chen, G. Z. (2014b). Produced water treatment technologies. International Journal of Low-Carbon Technologies, 9(3), 157-177. https:// doi.org/10.1093/ijlct/cts049

Jankhah, S., \& Bérubé, P. R. (2014). Pulse bubble sparging for fouling control. Separation and Purification Technology, 134(Supplement C), 58-65. https:// doi.org/10.1016/j.seppur.2014.07.023

Johnson, B. M., Kanagy, L. E., Rodgers, J. H., \& Castle, J. W. (2008). Chemical, Physical, and Risk Characterization of Natural Gas Storage Produced Waters. Water, Air, and Soil Pollution, 191(1), 33-54. https:/ / doi.org/10.1007/s11270-007-9605-8

Kim, C., Lee, S., \& Hong, S. (2012). Application of osmotic backwashing in forward osmosis: Mechanisms and factors involved. Desalination and Water Treatment, 43(1-3), 314-322. https:/ / doi.org/10.1080/19443994.2012.672215

Kim, E.-S., Liu, Y., \& Gamal El-Din, M. (2011). The effects of pre-treatment on nanofiltration and reverse osmosis membrane filtration for desalination of oil sands process-affected water. Separation and Purification Technology, 81(3), 418428. https:/ / doi.org/10.1016/j.seppur.2011.08.016

Klaysom, C., Cath, T. Y., Depuydt, T., \& Vankelecom, I. F. J. (2013). Forward and pressure retarded osmosis: Potential solutions for global challenges in energy and water supply. Chemical Society Reviews, 42(16), 6959-6989. https://doi.org/10.1039/c3cs60051c

Kobayashi, T., Kobayashi, T., Hosaka, Y., \& Fujii, N. (2003). Ultrasound-enhanced membrane-cleaning processes applied water treatments: Influence of sonic frequency on filtration treatments. Ultrasonics, 41(3), 185-190. https:/ / doi.org/10.1016/S0041-624X(02)00462-6

Lamminen, M. O., Walker, H. W., \& Weavers, L. K. (2004). Mechanisms and factors influencing the ultrasonic cleaning of particle-fouled ceramic membranes. Journal of Membrane Science, 237(1), 213-223. https:/ / doi.org/10.1016/j.memsci.2004.02.031

Lau, W. J., Ismail, A. F., Misdan, N., \& Kassim, M. A. (2012). A recent progress in thin film composite membrane: A review. Desalination, 287, 190-199. https:// doi.org/10.1016/j.desal.2011.04.004

Lee, S., Boo, C., Elimelech, M., \& Hong, S. (2010a). Comparison of fouling behavior in forward osmosis (FO) and reverse osmosis (RO). Journal of Membrane Science, 365(1), 34-39. https:// doi.org/10.1016/j.memsci.2010.08.036 
Lee, S., Boo, C., Elimelech, M., \& Hong, S. (2010b). Comparison of fouling behavior in forward osmosis (FO) and reverse osmosis (RO). Journal of Membrane Science, 365(1), 34-39. https:// doi.org/10.1016/j.memsci.2010.08.036

Lee, S., Shon, H. K., \& Hong, S. (2017). Dewatering of activated sludge by forward osmosis (FO) with ultrasound for fouling control. Desalination, 421, 79-88. https:/ / doi.org/10.1016/j.desal.2017.02.010

Leong, T., Ashokkumar, M., \& Kentish, S. (2011). THE FUNDAMENTALS OF POWER ULTRASOUND - $\quad A \quad$ REVIEW. http://minervaaccess.unimelb.edu.au/handle/11343/123494

Li, J.-Y., Ni, Z.-Y., Zhou, Z.-Y., Hu, Y.-X., Xu, X.-H., \& Cheng, L.-H. (2018). Membrane fouling of forward osmosis in dewatering of soluble algal products: Comparison of TFC and CTA membranes. Journal of Membrane Science, 552, 213221. https:/ / doi.org/10.1016/j.memsci.2018.02.006

Lutchmiah, K., Verliefde, A. R. D., Roest, K., Rietveld, L. C., \& Cornelissen, E. R. (2014). Forward osmosis for application in wastewater treatment: A review. Water Research, 58(Supplement $\quad$ C), 179-197. https:// doi.org/10.1016/j.watres.2014.03.045

Madaeni, S. S. (1999). The application of membrane technology for water disinfection. Water Research, 33(2), 301-308. https:/ / doi.org/10.1016/S0043-1354(98)00212-7 Masselin, I., Chasseray, X., Durand-Bourlier, L., Lainé, J.-M., Syzaret, P.-Y., \& Lemordant, D. (2001). Effect of sonication on polymeric membranes. Journal of Membrane Science, 181(2), 213-220. https://doi.org/10.1016/S03767388(00)00534-2

Mat Nawi, N., Bilad, M., Anath, G., Nordin, N., Kurnia, J., Wibisono, Y., \& Arahman, N. (2020). The Water Flux Dynamic in a Hybrid Forward Osmosis-Membrane Distillation for Produced Water Treatment. Membranes, 10(9), 225. https:/ / doi.org/10.3390/membranes10090225

Minier-Matar, J., Hussain, A., Janson, A., Wang, R., Fane, A. G., \& Adham, S. (2015). Application of forward osmosis for reducing volume of produced/Process water from oil and gas operations. Desalination, 376(Supplement C), 1-8. https:// doi.org/10.1016/j.desal.2015.08.008

Minier-Matar, J., Santos, A., Hussain, A., Janson, A., Wang, R., Fane, A. G., \& Adham, S. (2016). Application of Hollow Fiber Forward Osmosis Membranes for Produced and Process Water Volume Reduction: An Osmotic Concentration Process. Environmental Science \& Technology, 50(11), 6044-6052. https:/ / doi.org/10.1021/acs.est.5b04801

Mulder, M. (1996). Basic Principles of Membrane Technology. Springer Science \& Business Media.

Nadav, N. (1999). Boron Removal From Seawater Reverse Osmosis. Permeate Utilizing Selective Ion Exchange Resin. Desalination, 124, 131-135. https:/ / doi.org/10.1016/S0011-9164(99)00097-1

Nawi, N. I. M., Arifin, S. N. H. M., Hizam, S. M., Rampun, E. L. A., Bilad, M. R., Elma, M., Khan, A. L., Wibisono, Y., \& Jaafar, J. (2020). Chlorella vulgaris broth harvesting via stand-alone forward osmosis using seawater draw solution. Bioresource Technology Reports, 9, 100394. https:// doi.org/10.1016/j.biteb.2020.100394

Nguyen, N. C., Nguyen, H. T., Chen, S.-S., Nguyen, N. T., \& Li, C.-W. (2015). Application of forward osmosis (FO) under ultrasonication on sludge 
thickening of waste activated sludge. Water Science and Technology: A Journal of the International Association on Water Pollution Research, 72(8), 1301-1307. https:// doi.org/10.2166/wst.2015.341

Nourbakhsh, H., Emam-Djomeh, Z., Mirsaeedghazi, H., Omid, M., \& Moieni, S. (2014). Study of different fouling mechanisms during membrane clarification of red plum juice. International Journal of Food Science $\mathcal{E}$ Technology, 49(1), 58-64. https://doi.org/10.1111/ijfs.12274

Psoch, C., \& Schiewer, S. (2006). Anti-fouling application of air sparging and backflushing for MBR. Journal of Membrane Science, 283(1), 273-280. https:/ / doi.org/10.1016/j.memsci.2006.06.042

Rahm, B. G., \& Riha, S. J. (2012). Toward strategic management of shale gas development: Regional, collective impacts on water resources. Environmental $\begin{array}{llll}\text { Science } \mathcal{E} \quad \text { Policy, } & \text { 17(Supplement }\end{array}$ https:// doi.org/10.1016/j.envsci.2011.12.004

Rahm, D. (2011). Regulating hydraulic fracturing in shale gas plays: The case of Texas. Energy Policy, 39(5), 2974-2981. https:/ / doi.org/10.1016/j.enpol.2011.03.009

Razak, N. N. A. N., Rahmawati, R., Bilad, M. R., Pratiwi, A. E., Elma, M., Nawi, N. I. M., Jaafar, J., \& Lam, M. K. (2020). Finned spacer for enhancing the impact of air bubbles for membrane fouling control in Chlorella vulgaris filtration. Bioresource Technology Reports, 11, 100429. https:/ / doi.org/10.1016/j.biteb.2020.100429

Seppälä, A., \& Lampinen, M. J. (2004). On the non-linearity of osmotic flow. Experimental Thermal and Fluid Science, 28(4), 283-296. https:// doi.org/10.1016/j.expthermflusci.2003.10.001

Sirivedhin, T., McCue, J., \& Dallbauman, L. (2004). Reclaiming produced water for beneficial use: Salt removal by electrodialysis. Journal of Membrane Science, 243(1), 335-343. https:// doi.org/10.1016/j.memsci.2004.06.038

Soice, N. P., Maladono, A. C., Takigawa, D. Y., Norman, A. D., Krantz, W. B., \& Greenberg, A. R. (2003). Oxidative degradation of polyamide reverse osmosis membranes: Studies of molecular model compounds and selected membranes. Journal of Applied Polymer Science, 90(5), 1173-1184. https:// doi.org/10.1002/app.12774

Sourirajan, S., \& Agrawal, J. P. (1969). REVERSE OSMOSIS. Industrial E Engineering Chemistry, 61(11), 62-89. https:// doi.org/10.1021/ie50719a007

Spellman, F. R. (2013). Handbook of Water and Wastewater Treatment Plant Operations (3rd ed.). CRC Press.

Sutzkover-Gutman, I., \& Hasson, D. (2010). Feed water pretreatment for desalination plants. Desalination, 264(3), 289-296. https:// doi.org/10.1016/j.desal.2010.07.014

Tang, C. Y., She, Q., Lay, W. C. L., Wang, R., \& Fane, A. G. (2010). Coupled effects of internal concentration polarisation and fouling on flux behavior of forward osmosis membranes during humic acid filtration. Journal of Membrane Science, 354(1), 123-133. https:// doi.org/10.1016/j.memsci.2010.02.059

Thorsen, T. (2004). Concentration polarisation by natural organic matter (NOM) in NF and UF. Journal of Membrane Science, 233(1), 79-91. https:/ / doi.org/10.1016/j.memsci.2004.01.003 
Veil, J. A., Puder, M. G., \& Elcock, D. (2004). A white paper describing produced water from production of crude oil, natural gas, and coal bed methane. (ANL/EA/RP-112631). Argonne National Lab., IL (US). https:/ / doi.org/10.2172/821666

Veil, J. A., Puder, M. G., Elcock, D., \& Redweik, R. J. (2004). A White Paper Describing Produced Water from Production of Crude Oil, Natural Gas, and Coal Bed Methane. (ANL/EA/RP-112631). Argonne National Lab., IL (US). https:// doi.org/10.2172/821666

Velmurugan, V., \& Srithar, K. (2008). Prospects and scopes of solar pond: A detailed review. Renewable and Sustainable Energy Reviews, 12(8), 2253-2263. https:/ / doi.org/10.1016/j.rser.2007.03.011

Wang, F., \& Tarabara, V. V. (2008). Pore blocking mechanisms during early stages of membrane fouling by colloids. Journal of Colloid and Interface Science, 328(2), 464469. https:/ / doi.org/10.1016/j.jcis.2008.09.028

Wang, X., Hu, T., Wang, Z., Li, X., \& Ren, Y. (2017). Permeability recovery of fouled forward osmosis membranes by chemical cleaning during a long-term operation of anaerobic osmotic membrane bioreactors treating low-strength wastewater. Water Research, 123, 505-512. https:// doi.org/10.1016/j.watres.2017.07.011

Wibisono, Y., \& Bilad, M. R. (2020). Design of forward osmosis system. In Current Trends and Future Developments on (Bio-) Membranes (pp. 57-83). Elsevier. https:/ / doi.org/10.1016/B978-0-12-816777-9.00003-4

Xia, L., Law, A. W.-K., \& Fane, A. G. (2013). Hydrodynamic effects of air sparging on hollow fiber membranes in a bubble column reactor. Water Research, 47(11), 3762-3772. https:// doi.org/10.1016/j.watres.2013.04.042

Yu, Y., Lee, S., \& Maeng, S. K. (2016). Forward osmosis membrane fouling and cleaning for wastewater reuse. Journal of Water Reuse and Desalination, jwrd2016023. https:/ / doi.org/10.2166/wrd.2016.023

Zhang, S., Wang, P., Fu, X., \& Chung, T.-S. (2014a). Sustainable water recovery from oily wastewater via forward osmosis-membrane distillation (FO-MD). Water Research, 52(Supplement C), 112-121. https:// doi.org/10.1016/j.watres.2013.12.044

Zhang, S., Wang, P., Fu, X., \& Chung, T.-S. (2014b). Sustainable water recovery from oily wastewater via forward osmosis-membrane distillation (FO-MD). Water Research, 52(Supplement

C), 112-121. https:// doi.org/10.1016/j.watres.2013.12.044 